\title{
Pengaruh Strategi Pembelajaran Card Sort Terhadap Hasil Belajar Biologi Peserta Didik
}

\author{
Syamsiara Nur \\ Program Studi Pendidikan Biologi FMIPA Universitas Sulawesi Barat \\ e-mail : nur_syamsiara@yahoo.co.id
}

\begin{abstract}
Abstrak
Penelitian ini merupakan penelitian eksperimen yang bertujuan untuk menjawab pertanyaan, tentang pengaruh penerapan stategi pembelajaran card sort terhadap hasil belajar biologi peserta didik kelas X IPA SMA Negeri 2 Majene.Populasi dalam penelitian ini adalah seluruh peserta didik Kelas X IPA SMA Negeri 2 Majene tahun pelajaran 2014/2015. Dari 4 kelas X IPA, dipilih dua kelas yakni X IPA-3 sebagai kelompok eksperimen dan X IPA-2 sebagai kelompok kontrol. Instrumen penelitian yang digunakan adalah tes hasil belajar biologi. Desain penelitian yang digunakan adalah pre-post test control group design.Data diolah dengan menggunakan analisis statistika deskriptif dan analisis statistika inferensial. Hasil analisis statistika deskriptif menunjukkan bahwa hasil belajar peserta didik yang diajar dengan strategi pembelajaran card sort diperoleh nilai mean 2, 840 dengan standar deviasi 1,640. Sedangkan hasil belajar peserta didik yang diajar tanpa menggunakan strategi pembelajaran card sort diperoleh nilai mean 1, 640 dengan standar deviasi 1,036. Hasil analisis statistika inferensial menunjukkan bahwa hasil belajar peserta didik kelas X IPA SMA Negeri 2 Majene yang diajar dengan strategi pembelajaran card sort lebih baik daripada yang diajar tanpa menggunakan card sort pada materi pelestarian lingkungan karena setelah dilakukan pengujian hipotesis dengan menggunakan uji $t$, maka diperoleh $t$ hitung kelas eksperimen 12,389 $\geq t$ tabel 3,745 dan thitung kelas kontrol 7,915 $\geq t$ tabel 3,745 berarti hal ini menunjukkan bahwa $H_{0}$ ditolak dan $\mathrm{H}_{1}$ diterima.
\end{abstract}

Kata kunci : Strategi Pembelajaran Card Sort, Hasil Belajar Biologi.

\section{PENDAHULUAN}

Pendidikan adalah usaha sadar dan terencana untuk mewujudkan suasana belajar dan proses pembelajaran agar peserta didik secara aktif mengembangkan potensi dirinya untuk memiliki kekuatan spiritual, keagamaan, pengendalian diri, kepribadian kecerdasan, akhlak mulia serta keterampilan yang diperlukan dirinya, masyarakat, bangsa dan negara.Untuk menciptakan multi interaksi dalam proses pembelajaran agar pembelajaran berlangsung efektif dan efisien, maka guru harus menguasai beberapa stategi pembelajaran. Selain menguasai strategi, guru juga diharapkan selektif memilih strategi yang tepat sesuai dengan materi, tingkat kemampuan siswa, lingkungan dan kondisi sekolah.

Hasil observasi menunjukkan rendahnya data hasil belajar peserta didik, hal tersebut disebabkan proses oleh pembelajaran yang didominasi pembelajaran tradisional atau pembelajaran langsung. Proses pembelajaran yang demikian membuat hasil belajar peserta didik rendah. Untuk meningkatkan mutu pembelajaran secara khusus diperlukan perubahan dalam kegiatan proses belajar mengajar. Strategi belajar yang memberikan kesempatan kepada peserta didik untuk aktif belajar.

Pada pembelajaran IPA biologi, sangat diperlukan strategi pembelajaran yang tepat yang dapat melibatkan peserta didik dengan optimal baik secara intelektual maupun emosional, karena pengajaran biologi menekankan pada keterampilan proses. Oleh Karena itu, perlu menerapkan suatu strategi belajar yang dapat membantu peserta didik untuk memahami materi ajar dalam meningkatkan hasil belajar. Banyak macam strategi pembelajaran yang dapat digunakan dalam menyajikan materi pelajaran. Salah satu cara penyajian materi pelajaran yang 
diharapkan yaitu dapat meningkatkan hasil belajar peserta didik dengan cara menggunakan strategi pembelajaran aktif. Dengan demikian peneliti menerapkan penyajian masalah melalui permainan agar hasil belajar peserta didik dapat meningkat dan melibatkan peserta didik secara aktif dengan menggunakan strategi pembelajaran card sort.

Pembelajaran card sort merupakan strategi pembelajaran yang sederhana yang melibatkan secara langsung peserta didik aktif dalam proses pembelajaran. menyenangkan. Stategi pembelajaran card sort adalah peserta didik memilah dan memilih atau menyortir kartu yang sesuai dengan kata kunci yang diberikan oleh guru, strategi ini dapat mengungkapkan daya ingat atau recall terhadap materi pelajaran yang telah dipelajari peserta didik, selain itu keunggulan dari strategi ini adalah guru mudah menguasai kelas, mudah dalam pelaksanaannya, dapat diikuti oleh siswa yang jumlahnya banyak, dan mudah menyiapkannya serta guru mudah menerangkan dengan baik, sehingga peserta didik benar-benar dapat memahami dan mengingat pelajaran yang telah diberikan. Terbukti dalam penelitian yang telah dilakukan oleh Haryanto (2010) mengenai pengaruh strategi pembelajaran aktif Card Sort dan Index Card Match terhadap prestasi belajar peserta didik dimana hasil prestasi belajar peserta didik yang menggunakan strategi pembelajaran card sort dengan rata-rata 74,73 lebih baik dibandingkan dengan penggunaan strategi pembelajaran Index Card Match dengan rata-rata 69,679.

Strategi pembelajaran di atas merupakan gambaran pelaksanaan pembelajaran oleh guru kepada peserta didik dengan pendekatan yang dapat memunculkan pertanyaan yaitu apakah berpengaruh terhadap hasil belajar peserta didik melalui strategi pembelajaran card sort dalam penerapannya terhadap pembelajaran biologi khususnya pada materi pembelajaran.

\section{METODE PENELITIAN}

Penelitian ini menggunakan penelitian eksperimen dengan penelitian jenis preeksperimental design. Kelompok penelitian ini bertindak sebagai kelompok kontrol dan kelompok eksperimen, yaitu kelompok pertama adalah kelompok yang diajar dengan strategi pembelajan dan kelompok kedua adalah kelompok eksperimen yang di ajar dengan strategi pembelajaran card sort.

Desain penelitian yang digunakan dalam penelitian ini adalah "pre test - post test control group design". Untuk lebih jelas seperti pada Tabel 2.1

Tabel 1. Desain Penelitian

\begin{tabular}{|l|l|l|}
\hline Pre test & Perlakuan & Post test \\
\hline $\mathrm{A}$ & $\mathrm{X}$ & $\mathrm{V}_{1}$ \\
\hline $\mathrm{B}$ & - & $\mathrm{V}_{2}$ \\
\hline
\end{tabular}

( Sumber : Sugiono, 2007)

Sampel yang digunakan terdiri atas 2 kelas yaitu kelas X IPA 3 yang di ajar dengan strategi pembelajaran card sort, sedangkan X IPA 2 diajar dengan menggunakan metode konvensional.

Adapun instrumen penelitian yang digunakan dalam penelitian ini yaitu Tes. Tes merupakan alat atau prosedur yang digunakan untuk mengetahui atau mengukur sesuatu dalam suasana, dengan cara dan aturan-aturan yang sudah ditentukan (Arikunto, 2012)

Tes hasil belajar biologi disusun sendiri oleh peneliti dengan memperhatikan ruang lingkup materi tujuan pembelajaran khusus. Tes yang digunakan dalam bentuk pilihan ganda sebanyak 10 nomor dan essay sebanyak 3 nomor dengan skor jawaban nomor satu adalah 35 skor, nomor dua adalah 25 skor dan nomor tiga adalah 30 skor, soal essay berbentuk soal analisa. 


\subsection{Teknik Pengumpulan Data}

Data yang dikumpulkan dalam penelitian ini adalah data primer, yaitu data yang diperoleh atau dikumpulkan oleh peneliti secara langsung dari sumber datanya, dimana pengumpulan data dilakukan dengan menggunakan metode tes. Dengan memberikan ujian dalam bentuk pilihan ganda sebanyak 10 nomor. Dimana dalam proses penilaiannya untuk jawaban benar setiap soal diberi skor 1 . Sedangkan untuk jawaban salah atau sama sekali tidak menjawab maka diberi skor 0. Selanjutnya nilai tes didapatkan dengan menggunakan rumus :

Nilai peserta didik $=\frac{\text { Skor yang diperoleh peserta didik }}{\text { Skor total }} \times 100$

Tabel 2. Konversi Nilai Hasil Belajar

\begin{tabular}{|l|l|l|l|}
\hline Interval & Hasil Konversi & Predikat & Kategori \\
\hline 100 & 4.00 & A & Sangat Baik \\
\hline $75-99$ & $3.00-3.96$ & B & Baik \\
\hline $67-74$ & $2.00-2,68$ & C & Cukup \\
\hline $0-60$ & $0-1.00$ & D & Kurang \\
\hline
\end{tabular}

(Sumber : Adaptasi Kemendikbud,2013)

\subsection{Teknik Analisis Data}

Analisis data yang digunakan untuk mengolah data hasil penelitian ini adalah :

\subsubsection{Analisis Statistik Deskriptif}

Analisis statistika deskriptif digunakan untuk mendeskripsikan skor hasil belajar biologi yang diperoleh dari kelas eksperimen dan kelas kontrol. Gambaran tersebut diperoleh melalui kriteria nilai ketuntasan belajar dari setiap peserta didik.

2.2.2 Analisis Statistik Inferensial

Analisis statistik inferensial digunakan untuk menguji hipotesis. Uji yang digunakan dalam penelitian ini adalah analisis data uji T-test untuk menguji hipotesis.

\section{HASIL DAN PEMBAHASAN}

3.1 Hasil Penelitian

3.1.1 Analisis Statistik Deskriptif

3.1.1.1 Deskripsi Skor Hasil Belajar Biologi yang Diajar Dengan Menggunakan Strategi Pembelajaran Card Sort

Apabila nilai hasil belajar biologi peserta didik yang diajar dengan menggunakan pembelajaran card sort yang merupakan kelompok eksperimen dengan frekuensi peserta didik adalah 25 orang. Dibagi dalam 2 kategori, maka akan diperoleh seperti Tabel 3.1

Tabel 3. Distibusi Frekuensi Dan Persentase Skor Hasil Belajar Biologi yang Diajar Dengan Menggunakan Pembelajaran Card Sort

\begin{tabular}{|l|l|l|l|l|}
\hline \multirow{2}{*}{ Kategori } & Pre Test & \multicolumn{2}{|c|}{ Post Test } \\
\cline { 2 - 5 } & $\mathbf{N}$ & $\mathbf{\%}$ & $\mathbf{N}$ & $\mathbf{\%}$ \\
\hline Baik & 0 & 0 & 22 & $88 \%$ \\
\hline Kurang & 25 & $100 \%$ & 3 & $12 \%$ \\
\hline
\end{tabular}

(Sumber : Data Hasil Penelitian Yang Telah Dianalisis)

Tabel 3. menunjukkan hasil belajar biologi yang diperoleh peserta didik kelas X IPA-3 SMA Negeri 2 Majene yang diajar melalui penerapan strategi pembelajaran card sort sebagai 
kelas eksperimen yang digambarkan dalam skor rata-rata hasil belajar dibagi menjadi dua kategori, yakni :

a. Untuk kategori kurang, pada pre test skor hasil belajar biologi melalui penerapan strategi pembelajaran card sort skor yang diperoleh di bawah 67 yakni dengan frekuensi 25 orang dengan persentase sebesar 100\%. Sedangkan pada post test skor yang diperoleh di bawah 67 yakni dengan frekuensi 3 orang dengan persentase $12 \%$.

b. Untuk kategori baik, pada pre test skor hasil belajar biologi melalui penerapan strategi pembelajaran card sort yang memperoleh skor 67 atau diatas 67 yakni dengan frekuensi 0 orang (tidak ada) persentase $0 \%$. Sedangkan pada post test yang memperoleh skor 67 atau diatas 67 yakni dengan ferkuensi 22 orang dengan persentase $88 \%$.

3.1.1.2 Deskripsi Skor Hasil Belajar Biologi yang Diajar Tanpa Menggunakan Strategi Pembelajaran Card Sort

Apabila nilai hasil belajar biologi peserta didik yang diajar dengan menggunakan pembelajaran card sort yang merupakan kelompok kontrol dengan frekuensi peserta didik adalah 25 orang. Dibagi dalam 2 kategori, maka akan diperoleh distribusi dan persentase seperti Tabel 3.2

Tabel 4. Distibusi Frekuensi Dan Persentase Skor Hasil Belajar Biologi yang Diajar Tanpa Menggunakan Pembelajaran Card Sort

\begin{tabular}{|l|l|l|l|l|}
\hline \multirow{2}{*}{ Kategori } & \multicolumn{2}{|c|}{ Pre Test } & \multicolumn{2}{c|}{ Post Test } \\
\cline { 2 - 5 } & $\mathbf{N}$ & $\%$ & $\mathbf{N}$ & $\%$ \\
\hline Baik & 1 & $4 \%$ & 9 & $36 \%$ \\
\hline Kurang & 24 & $96 \%$ & 16 & $64 \%$ \\
\hline
\end{tabular}

(Sumber : Data Hasil Penelitian Yang Telah Dianalisis)

Tabel 4 menunjukkan hasil belajar biologi yang diperoleh peserta didik kelas X IPA-3 SMA Negeri 2 Majene yang diajar tanpa penerapan strategi pembelajaran card sort sebagai kelas kontrol yang digambarkan dalam skor rata-rata hasil belajar dibagi menjadi dua kategori yakni :

a. Untuk kategori kurang, pada pre test skor hasil belajar biologi melalui penerapan strategi pembelajaran card sort skor yang diperoleh di bawah 67 yakni dengan frekuensi 24 orang dengan persentase sebesar $96 \%$ sedangkan pada post test skor yang diperoleh di bawah 67 yakni dengan frekuensi 16 orang dengan persentase $64 \%$.

b. Untuk kategori baik, pada pre test skor hasil belajar biologi melalui penerapan strategi pembelajaran card sort yang memperoleh skor 67 atau diatas 67 yakni dengan frekuensi 1 orang dengan persentase $4 \%$ sedangkan pada post test yang memperoleh skor diatas 67 yakni dengan ferkuensi 9 orang dengan persentase $36 \%$.

3.1.2 Analisis Statistik Inferensial

Hasil analisis deskriptif menunjukkan tentang karakteristik distribusi skor masingmasing variabel dan sekaligus merupakan jawaban atas masalah deskriptif yang dirumuskan dalam penelitian ini. Sesuai dengan hipotesis penelitian, maka teknik yang digunakan untuk menguji hipotesis tersebut adalah teknik statistik (uji-t). Berikut hasil analisis Uji T- test disajikan dalam Tabel 5.

Tabel 5. Analisis Uji T-test

\begin{tabular}{|c|c|c|c|c|c|c|c|}
\hline \multirow[b]{2}{*}{ Responden } & \multicolumn{2}{|c|}{ Pre test } & \multicolumn{2}{|c|}{ Post Test } & \multicolumn{2}{|c|}{ Perubahan } & \multirow{2}{*}{$\begin{array}{l}\text { Sign } \\
2- \\
\text { tailed }\end{array}$} \\
\hline & Mean & $\mathrm{Sd}$ & Mean & $\mathrm{Sd}$ & Mean & $\mathrm{Sd}$ & \\
\hline Eksperimen & 4,480 & 1,045 & 7,320 & 0,690 & 2,840 & 1,106 & 0,000 \\
\hline Kontrol & 4,560 & 1,121 & 6,200 & 1,154 & 1,640 & 1,036 & 0,000 \\
\hline
\end{tabular}

(Sumber : Data Hasil Penelitian Yang Telah Dianalisis) 
Tabel 5 menunjukkan bahwa pada kelompok eksperimen dan kelompok kontrol mengalami perubahan pada pre-post test setelah diuji T-test. Nilai mean pada kelompok eksperimen 2,480 dan pada kelompok kontrol 1,640 demikian pula pada standar deviasi pada kelompok eksperimen 1,106 dan pada kelompok kontrol 1,036. Dari nilai mean dan standar deviasi yang diperoleh pada kelompok eksperimen dan kelompok kontrol terdapat perbedaan yang signifikan.

\section{Hasil Pengujian Hipotesis}

Berdasarkan hasil analisis data, jika $t$ hitung $\geq \mathrm{t}$ tabel maka $\mathrm{H}_{\mathrm{o}}$ ditolak dan $\mathrm{H}_{1}$ diterima dengan taraf signifikan $\alpha=0,05$. Berikut perbandingannya seperti dalam Tabel 3.4

Tabel 6. Perbandingan Nilai t Hitung dan t Tabel

\begin{tabular}{|l|l|l|}
\hline Kelas & t Hitung & t Tabel \\
\hline Eksperimen & 12,389 & 3,745 \\
\hline Kontrol & 7,915 & 3,745 \\
\hline
\end{tabular}

(Sumber : Data Hasil Penelitian Yang Telah Dianalisis)

Tabel 6 menunjukkan bahwa $\mathrm{H}_{\mathrm{o}}$ ditolak dan $\mathrm{H}_{1}$ diterima maka dapat disimpulkan bahwa strategi pembelajaran card sort memberikan pengaruh terhadap hasil belajar biologi peserta didik kelas X IPA SMA Negeri 2 Majene yang diajar menggunakan pembelajaran card sort daripada yang diajar tanpa menggunakan pembelajaran card sort.

3.2 Pembahasan

Berdasarkan hasil analisis deskriptif, nilai mean pada kelompok eksprimen pre-post test yakni 4,480 menjadi 7,320. Hal tersebut mengalami perubahan yang lebih baik terhadap hasil belajar biologi peserta didik. Sedangkan pada kelompok kontrol pre-post test yakni 4,560 menjadi 6,200 juga mengalami perubahan seperti pada kelompok kontrol namun hasil belajar lebih memberi pengaruh yang lebih baik pada kelompok eksperimen yang diajar dengan menggunakan strategi card sort daripada yang tanpa menggunakan card sort.

Berdasarkan hasil analisis data uji T-test juga menunjukkan adanya pengaruh, dimana kelompok eksperimen yang menggunakan pembelajaran card sort dengan kelompok kontrol yang tanpa mengggunakan card sort terdapat perbedaan yang signifikan terhadap hasil belajar biologi, ditunjukkan dari nilai t hitung $\geq \mathrm{t}$ tabel maka $\mathrm{H}_{\mathrm{o}}$ ditolak dan $\mathrm{H}_{1}$ diterima.

Hasil analisis data yang telah diperoleh, ternyata cukup mendukung teori yang telah dikemukakan pada tinjauan pustaka. Bila ditinjau dari keterlibatan peserta didik dalam proses belajar mengajar. Pada saat eksperimen, peserta didik yang diajar dengan menggunakan pembelajaran card sort tampak kolaboratif dan lebih bersemangat dalam menerima pelajaran, karena sajian materi pelajaran dalam bentuk kartu berwarna. Peserta didik dibagikan kertas berisi kata kunci kemudian mencari dan mencocokkannya dengan kata kunci berwarna yang terletak di depan kelas sebagai jawaban dari soal tersebut, sehingga peserta didik diharapkan mampu menjelaskan hasil kerjanya kepada teman-teman yang lain.

Terbukti dalam juga dalam penelitian yang telah dilakukan oleh Haryanto (2010) mengenai pengaruh strategi pembelajaran aktif Card Sort dan Index Card Match terhadap prestasi belajar peserta didik dimana hasil prestasi belajar peserta didik yang menggunakan strategi pembelajaran Card Sort dengan rata-rata 74,73 lebih baik dibandingkan dengan penggunaan strategi pembelajaran Index Card Match dengan rata-rata 69,679.

Tiro dalam Suarni (2002) mengemukakan bahwa keberhasilan proses pengajaran dapat dilihat dari (1) meningkatnya nilai rata-rata, (2) berubahnya bentuk distribusi dari miring positif menjadi miring negatif, (3) koefisien variasi semakin mengecil.Card sort merupakan kegiatan kolaboratif yang bisa digunakan untuk mengajarkan konsep, penggolongan sifat, fakta tentang suatu objek, atau mengulangi informasi. Card sort lebih mengutamakan gerakan fisik yang dapat membantu untuk memberi energi kepada kelas yang telah letih/ kurang bersemangat (Silberman dalam Mulyono, 2011). 
Penerapan pembelajaran card sort dapat mengungkapakan daya ingat atau recall terhadap materi pelajaran yang telah dipelajari peserta didik, selain itu dapat menciptakan kondisi yang membutuhkan kerja sama yang baik antara anggota kelas dan terbentuknya kreativitas peserta didik dalam menemukan jawaban yang tepat.

Jika dibandingkan dengan peserta didik yang diajar tanpa pembelajaran card sort keterlibatan peserta didik tidak terlalu nampak. Peserta didik memiliki kecendrungan untuk menunggu jawaban dari guru. Dengan kata lain, peseta didik yang diajar dengan menggunakan pembelajaran card sort lebih aktif baik fisik maupun intelektualnya, sedangkan peserta didik yang diajar tanpa pembelajaran card sort lebih bersifat pasif karena tidak ditantang oleh suatu masalah dan mereka cenderung menunggu jawaban dari guru.

\section{KESIMPULAN}

Berdasarkan hasil analisis data penulisan dan pembahasan hasil penelitian maka dapat ditarik beberapa kesimpulan sebagai berikut:

1. Hasil belajar biologi peserta didik kelas X IPA SMA Negeri 2 Majene yang diajar dengan pembelajaran card sort, pada materi pelestarian lingkungan dengan skor rata-rata 2,480 dengan standar deviasi 1,106 berada pada kategori baik.

2. Hasil belajar biologi peserta didik yang diajar tanpa pembelajaran card sort, pada materi pelestarian lingkungan dengan skor rata-rata 1,640 dengan standar deviasi 1,036 berada pada kategori kurang.

3. Terdapat perbedaan hasil belajar hasil belajar peserta didik kelas X IPA SMA eri 2 Majene yang diajar menggunakan pembelajaran card sort dengan yang tanpa men $z$ zunlakan card sort, diperoleh t hitung pada kelas eksperimen 12,389 dan pada kelas kontrol 7,915 dengan nilai t tabel 3,745 .

\section{DAFTAR PUSTAKA}

Arikunto, Suharsimi. 2011. Dasar-Dasar Evaluasi Pendidikan. Edisi Revisi. Bumi Aksara : Jakarta.

Asril Zainal. 2012. Micro Teaching. Raja Grafindo Persada : Jakarta.

Bahrissalim dan Abdul Haris. 2012. Modul Pendidikan Dan Latihan Profesi Guru (PLPG). Direktorat Pendidikan : Makassar.

Daryanto, 2009. Panduan Proses Pembelajaran Kreatif dan Inovatif. AV Publisher

Haryanto. 2010. Pengaruh Strategi Pembelajaran Aktif Card Sort dan Index Card Match Terhadap Prestasi Belajar Getaran dan Gelombang. (Skripsi). Institut Keguruan dan Ilmu Pendidikan : Semarang.

Hasbullah. 2005. Dasar-Dasar Ilmu Pendidikan Edisi Revisi. PT Raja Grafindo:Jakarta.

Isjoni. 2012. Cooperative Learning Mengembangkan Kemampuan Belajar Berkelompok. Alfabeta : Bandung.

Mulyono, I, H. 2011. Pembelajaran Active Learning Card. Sumber, http://imam hadi mulyono .blogspot. com/ 2011/ 11/ pembelajaran- aktif- active-learning-card.html. Diakses pada hari Minggu 4 Januari 2015 pukul 10.15 WITA.

Munawar Indra. 2009. Hasil Belajar, Pengertian dan Definisi. Sumber, http:// indra munawar.blogspot. com/ 2009/06/ hasil-belajar-pengertian-dan-definisi. html. Diakses pada hari Jumat 16 Januari 2015, pukul 12.03 WITA.

Mutiah,Haerul. 2010. Pengaruh Penerapan Metode Stimulus-Respon Dalam Meningkatkan Hasil Belajar Peserta didik. (Skripsi). Universitas Islam Negeri Bulukumba.

Pitoyo Ari. 2013. BIOLOGI Untuk SMA/MA Kelas X. PT. Masmedia Buana Pustaka : Sidorajo.

Rohani A. 2004. Pengelolaan Pengajaran. PT Rineka Cipta. : Jakarta. 
Rusman. 2010. Model-Model Pembelajaran. Rajawali pers: Bandung.

Sainab. 2011. Belajar dan Pembelajaran. Majene: Universitas Sulawesi Barat.

Suradi. 2005. Tinjauan tentang Implementasi Pembelajaran Kooperatif dalam Pembelajaran

Matematika. Jurnal Ilmu Kependidikan. Universitas Negeri Makassar

Suarni. 2002. Penerapan Strategi Pembelajaran Advanced Organizer Dalam Pengajaran Pokok Bahasan Tempat Kedudukan Di kelas II SLTP Negeri 26 Makassar. (Skipsi). Universitas Sulawesi Barat.

Sugiyono. 2010. Metode Penelitian Pendidikan. Alfabeta.: Bandung.

Syah Muhibbin. 2005. Psikologi Belajar. PT Raja Grafindo Persada. : Jakarta.

Trianto. 2010. Mendesain Model Pembelajaran Inofatif Dan Progresif. Kencana : Jakarta

Yatim Rianto. 2010. Paradigma Baru Pembelajaran. Kencana : Jakarta.

Zaif. 2012. Card Sort. Sumber http://zaifbio.wordpress.com/2012/tag/card-sort/. Diakses pada hari Jumat, 16 Januari 2015, pukul 10.35 WITA. 